\title{
PENGARUH IMBANGAN HIJAUAN DENGAN KONSENTRAT DALAM RANSUM TERHADAP KINERJA SAPI JANTAN PERANAKAN FRIESIAN HOLSTEIN
}

\author{
Eka Handayanta ${ }^{1}$
}

\section{INTISARI}

Penelitian ini bertujuan untuk mengetahui pengaruh perbandingan hijauan dengan konsentrat dalam ransum terhadap kinerja sapi jantan Peranakan Friesian Holstein (PFH), telah dilaksanakan di perusahaan peternakan sapi perah “ Mawar Mekar" farm, Gedong, Karanganyar, Jawa Tengah. Sembilan ekor sapi jantan PFH dengan rata-rata berat badan awal $132,77 \mathrm{~kg}$ digunakan dalam penelitian ini. Sapi-sapi tersebut secara acak dikelompokkan menjadi 3 kelompok perlakuan dan masing-masing kelompok terdiri dari 3 ekor sebagai ulangan (individual). Pakan yang digunakan berupa hijauan dengan konsentrat ( $\%$ dasar $B K)$ yang berturut-turut $=15 ; 85\left(R_{1}\right), 25: 75\left(R_{2}\right)$ dan $35: 65\left(R_{3}\right)$. Ransum penelitian dibuat iso nitrogen dan iso energi, dan diberikan sebesar $3 \%$ (dasar BK) dari berat badan ternak. Air minum diberikan secara ad libitum. Daii hasil penelitiar dapat disimpulkan bahwa imbangan hijauan (15 - $35 \%)$ dengan konsentrat $(65-85 \%)$, berpengaruh nyata terhadap konsumsi BK, PK, dan TDN, tetapi berpengaruh tidak nyata terhadap pertambahan berat badan dan konversi pakan. Ada kecendenungan semakin tinggi porsi konsentrat dalam ransum semakin tinggi pertambahan berat badan yang dicapai dan semakin efisien penggunaan pakannya.

(Kata kunci : Hijauan, Konsentrat, Kinerja, Sapi jantan PFH).

Buletin Peternakan 24 (4): $157-163,2000$

'Akademi Peternakan Karanganyar - Jawa Tengah. 


\section{EFFECT OF RATIO BETWEEN FORAGE AND CONCENTRATE IN THE RATION ON PERFORMANCE OF MALE FRIESIAN HOLSTEIN CROSSBRED}

ransum

$85 \%$ d

$12,8 \%$

ADG :

melapor

pakan $\mathrm{k}$

imbanga

dan en

15,$62 ; 17$

turut me

$\mathrm{kg} / \mathrm{ekor} /$

dalam pe

jantan

dengan :

$\%$ dasar

ADG set

significant effect on the consumption of dry matter, crude protein and total digestible nutrients (TDN), but has not significant effect on daily gain and feed conversion. There was a tendency that higher concentrate in the ration, the higher daily gain and the feed efficiency will be.

(Key words : Forage, Concentrate, Performance, Friesian Holstein crossbreed).

\section{Pendahuluan}

Pakan ternak sapi pada dasarnya terdiri dari 2 (dua) golongan yaitu hijauan dan konsentrat. Hijauan adalah bahan pakan yang mempunyai kadar serat kasar (SK) tinggi, sedangkan konsentrat mempunyai kadar SK rendah, mudah dicerna, mengandung pati dan protein kasar (PK) yang tinggi, sehingga nutriennya lebih tinggi dibanding hijauan.

Produk akhir utama dari pencernaan di dalam rumen dari pakan yang kaya serat kasar adalah asam asetat $\left(\mathrm{C}_{2}\right)$ sedangkan pakan yang kaya akan pati akan dihasilkan asam propionat $\left(C_{3}\right)$ yang lebih banyak (Arora, 1989, Tillman et al., 1994). Asam asetat merupakan prekursor bagi pembentukan lemak susu, sedangkan asam propionat merupakan prekursor pembentukan lemak daging. Oleh karena itu imbangan antara asam asetat dengan asam propionat sering digunakan sebagai indikator untuk mengetahui kualitas produk yang dihasilkan. Jika imbangan antara asam asetat dengan asam propionat $\left(\mathrm{C}_{2} / \mathrm{C}_{3}\right)$ rendah, maka akan merangsang penggemukan, sehingga pakan dengan imbangan hijauan dengan konsentrat rendah cocok untuk penggemukan (Suryapratama, 1989). Dinyatakan pula oleh Sutardi $(1980)$, bahwa pola produksi asam lemak volatil (VFA) dalam rumen dapat diubah dan disesuaikan dengan tujuan produksi. Untuk penggemukan sapi pedaging dikehendaki imbangan asam asetat dengan asam propionat yang rendah, sebab asam propionat dapat dimanfaatkan lebih baik untuk pembentukan lemak tubuh.

Sapi perah jantan yang tidak digunakan sebagai pejantan dapat diarahkan sebagai penghasil daging (penggemukan) Sapi Friesian Holstein (FH) jantan muda mempunyai pertumbuhan yang cepat dengan efisiensi pakan yang sangat baik, produksi daging cukup banyak dan berkualitas tinggi (Miller, 1979). Potensi sapi jantan FH sebagai ternak potong penghasil daging terlihat dari beberapa hasil penelitian yang telah dilakukan, yang menunjukkan kenaikan berat badan hariannya atau average daily gain (ADG) cukup tinggi. Sumadi at al, (1991) dalam penelitiannya, bahwa sapi jantan $\mathrm{FH}$ dengan komposisi dengan

$132,77 \mathrm{k}$

Sapi-sapi

3 tingkat

terdiri dar

Rancanga

adalah ra

Bahan pa

rumput $\mathbf{R}$

bekatul (

onggok

bungkil kı

bungkil ke

BK

kasar (cruc

nutrients.

Sumber : S 
ransum (hijauan dengan konsentrat) $=15$ $85 \%$ dasar $\mathrm{BK}$, dengan kandungan $\mathrm{PK}=$ $12,8 \%$ dan TDN : $66,36 \%$, mendapatkan ADG : 0,91 kg/ekor/hari. Sitorus et al. (1991), melaporkan bahwa sapi jantan FH yang diberi pakan konsentrat dengan rumput gajah dengan imbangan $3: 1$ dasar BK, kandungan PK (\%) dan energi (Kj) masing-masing 19,92 dan 15,$62 ; 17,76$ dan 15,$41 ; 15,63$ dan 15,19 berturutturut memberikan ADG : 1,15; 1,10 dan 0,99 kg/ekor/hari, sedangkan Handayanta (1994) dalam penelitiannya dengan menggunakan sapi jantan FH yang diberi ransum (hijauan dengan konsentrat) dengan imbangan 15:85 $\%$ dasar BK, PK ransum 13,22\% didapatkan ADG sebesar $0,92 \mathrm{~kg} / \mathrm{ekor} / \mathrm{hari}$.

\section{Materi dan Metode}

Sejumlah 9 ekor sapi jantan PFH dengan rata-rata berat badan (BB) awal \pm $132,77 \mathrm{~kg} / \mathrm{ekor}$ digunakan dalam penelitian ini. Sapi-sapi tersebut dibagi secara acak ke dalam 3 tingkat perlakuan dan tiap-tiap perlakuan terdiri dari 3 ekor sebagai ulangan (individual). Rancangan yang digunakan dalam penelitian ini adalah rancangan acak lengkap (completely randomized design) pola searah. Pakan yang diberikan adalah hijauan (rumput Raja) dan konsentrat. Bahan penyusun konsentrat dan komposisi kimianya seperti disajikan pada Tabel I dan 2. Perlakuan yang diberikan adalah imbangan antara hijauan dengan konsentrat (\% dasar $B K$ ) yakni 15:85 $\left(\mathrm{R}_{1}\right) ; 25: 75\left(\mathrm{R}_{2}\right)$ dan $35: 65 \quad\left(R_{3}\right)$. Ransum penelitian dibuat isonitrogen dan iso energi. Susunan ransum dan kandungan PK dan TDN disajikan pada Tabel 3. Pakan diberikan sebesar $3 \%$ dari berat badan sapi (dasar BK), dan air minum diberikan secara ad libitum. Lama penelitian satu bulan (data collection) dan pengukuran berat badan sapi dilakukan dengan menggunakan pita ukur untuk menguk"'r lingkar dada (Anonim, 1998).

Data yang diperoleh meliputi : konsumsi BK, konsumsi PK, konsumsi TDN, dan konversi pakan dianalisis variansi sedangkan pertambahan berat badan (PBB) di analisis menggunakan analisis kovariansi dengan berat badan awal sebagai covariate-nya dan untuk mengetahui perbedaan diantara perlakuan digunakan uji Duncan (Duncan's New Multiple Range Test), (Astuti, 1980).

Tabel 1. Komposisi kimia bahan-bahan penyususun ransum penelitian (Chemical composition of feedstuffs)

\begin{tabular}{lccccc}
\hline & \multicolumn{5}{c}{$\%$ dasar bahan kering (BK) (\% dry matter basic) } \\
\cline { 2 - 6 } Bahan pakan (feedstuffs) & BK & PK & \multicolumn{1}{c}{ SK } & EE & TDN \\
\hline rumput Raja (King grass) & 22,4 & 13,5 & 34,1 & 3,5 & 57 \\
bekatul (rice bran) & 87,5 & 13,8 & 8,4 & 9,4 & 50 \\
onggok (cassava pomace) & 88,7 & 1,2 & 11,0 & 0,2 & 85 \\
bungkil kelapa (copra meal) & 87,9 & 21,1 & 13,1 & 17,3 & 81 \\
bungkil kedelai (soybean meal) & 88,6 & 41,3 & 8,6 & 15,0 & $77^{11}$ \\
\hline \multicolumn{1}{c}{ BK = bo }
\end{tabular}

$\mathrm{BK}=$ bahan kering (dry matter, DM), $\mathrm{PK}=$ protein kasar $($ crude protein, $C P), \mathrm{SK}=$ serat kasar (crtte fiber, (F). EE = ekstrak ether (ether extract, EE) dan TDN $=$ total digestible mitrients.

Sumber : Siregar (1994)

1) Lomboan (1992) 
Tabel 2. Bahan penyusun konsentrat, kandungan PK dan TDN (dasar BK) (Feedstuffs, CP and TDN content (\% DM basic)

\begin{tabular}{lc}
\hline Bahan pakan (feedstuffs) & Persentase (\%) (percentage (\%) \\
\hline Bahan (feed stuff) : & 55 \\
Bekatul (rice bran) & 20 \\
Onggok (cassava pomace) & 15 \\
Bungkil kelapa (copra meal) & 10 \\
Bungkil kedelai (soybean meal) & \\
Kandungan (content): & 15,26 \\
PK (crude protein) & 64,35 \\
Nutrien tercerna total $(T D N)$ &
\end{tabular}

Tabel 3. Susunan ransum penelitian, kandungan PK dan TDN ( $\%$ dasar BK) (Formulation ration CP and TDN contem, \% DM basic)

\begin{tabular}{lccc} 
& \multicolumn{3}{c}{ Perlakuan (ransum) (treatment, ration) } \\
\cline { 2 - 4 } Bahan (ingredients) & $\mathbf{R}_{\mathbf{1}}$ & $\mathbf{R}_{2}$ & $\mathbf{R}_{\mathbf{3}}$ \\
\hline Bahan (ingredients) : & 15 & 25 & 35 \\
$\quad$ Rumput Raja (King grass) & 85 & 75 & 65 \\
$\quad$ Konsentrat (concentrate) & & & \\
Kandungan') (content 1): & 14,87 & 14,75 & 14,58 \\
PK (crude protein) & 63,25 & 62,51 & 61,78 \\
Nutrien tercerna total (TDN) &
\end{tabular}
chemical composition on Table $I$ and 2).

\section{Hasil dan Pembahasan}

Kinerja sapi-sapi hasil penelitian yang meliputi konsumsi BK, konsumsi PK, konsumsi TDN, pertambahan BB dan konversi pakan seperti disajikan pada Tabel 4

\section{Konsumsi bahan kering}

Hasil analisis statistik menunjukkan bahwa perbandingan hijauan dengan konsentrat dalam ransum berpengaruh nyata $(P<0,05)$ terhadap konsumsi BK pakan. Dengan kata lain bahwa besarnya konsumsi BK sapi jantan PFH dipengaruhi oleh perbandingan hijauan dengan konsentrat dalam ransumnya.

Hasil uji lanjut menunjukkan bahwa kelompok sapi yang mendapatkan ransum $\mathbf{R}_{\mathbf{l}}$ mengkonsumsi $\mathrm{BK}$ lebih rendah dibandingkan kelompok sapi yang mendapatkan ransum $\mathbf{R}_{2}$ dan $R_{3}$, sedangkan antara $R_{2}$ dengan $R_{3}$ jumlah konsumsinya berbeda tidak nyata. Perbedaan jumlah konsumsi BK ransum ini lebih disebabkan oleh perbedaan berat badan sapi percobaan yang digunakan. Seperti terlihat pada Tabel 4 bahwa rata-rata $B$ B awal kelompok sapi pada $R_{1}$ jauh lebih rendah daripada kelompok sapi pada $R_{2}$ maupun $R_{3}$ (93 kg vs $149 \mathrm{~kg}$ dan $156,33 \mathrm{~kg}$ ). Seperti dinyatakan oleh Tillman et al. (1994), babwa ternak yang lebih besar membutuhkan pakan yang lebih banyak untuk memenuhi kebutuhan hidup pokoknya, karena nutrien yang dibutuhkan juga lebih banyak (Siregar, 1994). Juga ditambahkan bahwa semakin tinggi berat badan sapi yang digemukkan dan dengan pertambahan berat badan yang dikehendaki sama, maka akan semakin tinggi pula kebutuhan pakannya (NRC, 1976). \begin{tabular}{r} 
Variabl \\
\hline Berat b \\
Berat b \\
Pertaml \\
Konsun \\
Konsun \\
Konsun \\
Konsun \\
Konver: \\
a,1 \\
$(a$,
\end{tabular}

Konsum:

bahwa $\mathrm{k}$ penelitian $(\mathrm{P}<0,05)$. kelompok mengkons kelompok maupun $\mathrm{F}$ antara $R_{2}$ 。 $\mathrm{Ke}$

besarnya $\mathrm{k}$ masing-ma yang mana daripada $\mathrm{R}$ PK dari $n$ (isonitroge pernyataan sapi dan de sama, mak protein kas

Konsumsi Hasi bahwa kons ransum pe yang nyat menunjukka mendapatka 
Tabel 4. Konsumsi BK, konsumsi PK, konsumsi TDN, PBB dan konversi pakan (DM consumption, CP consumption. TDN consumption, daily gain and feed conversion)

Variable (Variables)

Berat badan awal (kg/ekor) (initial liveweight, $\mathrm{kg} / \mathrm{ome})^{\mathrm{ns}}$ Berat badan akhir (kg/ekor) (final liveweight, $\mathrm{kg}$ one) ${ }^{\text {ns }}$ Pertambahan BB (kg/ekor/hari) (daily gain, kg/one day) ${ }^{\text {ns }}$ Konsumsi BK (g/ekor/hari) (DM conswmption. g one/day) Konsumsi BK (\%BB) (DM consumption, \% liveweight $)^{\text {ns }}$ Konsumsi PK (g/ekor/hari) (CP constamption, $g$ one day) Konsumsi TDN (g/ekor/hari) (TDN consumption, $g$ one day) Konversi pakan (feed comversion) ${ }^{\text {ms }}$

$a, b$ - superskrip yang berbeda pada baris yang sama menunjukkan perbedaan $(P<0,05)$

( $a, b:$ superscript in the same row indicate significanly different $(P<0,05)$ )

Perlakuan (Treatment)

\begin{tabular}{ccc}
$\mathbf{R}_{1}$ & $\mathbf{R}_{\mathbf{2}}$ & $\mathbf{R}_{\mathbf{3}}$ \\
\hline 93,00 & 149,00 & 156,33 \\
123,33 & 176,00 & 180,33 \\
1,01 & 0,90 & 0,80 \\
$3,22^{a}$ & $4,54^{b}$ & $4,59^{b}$ \\
3,46 & 3,05 & 2,94 \\
$0,38^{\text {a }}$ & $0,68^{\text {b }}$ & $0,68^{\mathrm{b}}$ \\
$2,14^{\mathrm{a}}$ & $2,87^{\mathrm{b}}$ & $2,89^{\mathrm{b}}$ \\
3,20 & 5,15 & 7,44
\end{tabular}

\section{Konsumsi protein kasar}

Hasil analisis statistik menunjukkan bahwa konsumsi PK ketiga macam ransum penelitian menunjukkan perbedaan yang nyata $(\mathrm{P}<0,05)$ Hasil uji lanjut menunjukkan bahwa kelompok sapi yang mendapatkan ransum $R_{1}$ mengkonsumsi PK lebih rendah dibandingkan kelompok sapi yang mengkonsumsi ransum $\mathbf{R}_{2}$ maupun $R_{3}$, sedangkan jumlah konsumsi $\mathbf{P K}$ antara $R_{2}$ dengan $R_{3}$ berbeda tidak nyata.

Keadaan tersebut berkaitan erat dengan besarnya konsumsi BK dan kandungan PK dari masing-masing ransum penelitian (Tabel 3), yang mana konsumsi $\mathrm{BK}$ pada $\mathrm{R}_{1}$ lebih rendah daripada $R_{2}$ maupun $R_{3}$. Disisi lain kandungan PK dari masing-masing ransum relatif sama (isonitrogen). Keadaan ini juga sesuai dengan pernyataan bahwa semakin tinggi berat badan sapi dan dengan pertambahan berat badan yang sama, maka semakin tinggi pula kebutuhan protein kasarnya (NRC, 1976).

\section{Konsumsi energi (TDN)}

Hasil analisis statistik menunjukkan bahwa konsumsi energi (TDN) ketiga macam ransum penelitian menunjukkan perbedaan yang nyata $(\mathrm{P}<0,05)$. Hasil uji lanjut menunjukkan bahwa kelompok sapi yang mendapatkan ransum $R_{l}$ mengkonsumsi TDN lebih rendah dibandingkan dengan kelompok sapi yang mengkonsumsi ransum $\mathbf{R}_{2}$ maupun $R 3$, sedangkan antara $R_{2}$ dengan $R_{3}$ berbeda tidak nyata

Keadaan tersebut berkaitan erat dengan konsumsi BK dengan kandungan TDN dari masing-masing ransum penelitian (Tabel 3), yang mana konsumsi BK pada $\mathbf{R}_{1}$ lebih rendah daripada $R_{2}$ maupun $R_{3}$, disisi lain kandungan TDN masing-masing ransum relatif sama (isoenergi). Hal ini juga sesuai pendapat yang menyatakan bahwa semakin tinggi berat badan sapi, semakin tinggi pula kebutuhan TDN nya (NRC, 1976). Lebih lanjut dinyatakan juga bahwa kebutuhan energi meningkat dengan semakin tingginya porsi hijauan dalam ransum.

\section{Pertambahan berat badan}

Hasil analisis statistik menunjukkan bahwa PBB ketiga kelompok sapi-sapi penelitian menunjukkan perbedaan yang tidak nyata. Dengan kata lain bahwa PBB sapi jantan PFH tidak dipengaruhi oleh perbandingan hijauan dengan konsentrat dalam ransumnya.

Secara kuantitatif dari data rata-rata PBB, bahwa semakin tinggi porsi konsentrat dalam ransum semakin tinggi PBB yang diperoleh. Hal ini kemungkinan disebabkan oleh imbangan asam asetat dengan asam 
propionat $\left(\mathrm{C}_{2} / \mathrm{C}_{3}\right)$ hasil pencernaan pakan di dalam rumen semakin rendah dengan semakin tingginya porsi konsentrat dalam ransum. Hal ini diharapkan dalam penggemukan sapi potong, karena asam propionat akan merangsang pembentukan lemak tubuh (penggemukan). Seperti dinyatakan oleh Arora (1989) dan Tillman et al. (1994) bahwa produk akhir utama pencernaan konsentrat di dalam rumen adalah asam propionat, sedangkan pencernaan hijauan akan menghasilkan asam asetat. Lebih lanjut dijelaskan bahwa asam propionat merupakan prekursor pembentukan lemak daging.

\section{Konversi pakan}

Hasil analisis statistik menunjukkan bahwa konversi pakan ketiga macam ransum penelitian menunjukkkan perbedaan yang tidak nyata. Dengan kata lain bahwa nilai konversi pakan tidak dipengaruhi oleh perbandingan hijauan dengan konsentrat dalam ransum.

Ada kecenderungan semakin tinggi porsi konsentrat dalam ransum semakin efesien penggunaan pakan/ransumnya (nilai konversi pakannya semakin turun/rendah). Seperti terlihat berturut-turut dari $\mathbf{R}_{3}, \mathbf{R}_{2}$ dan $\mathbf{R}_{1}$ masing-masing 7,$44 ; 5,15$ dan 3,20 . Hal ini sesuai dengan pendapat Jesse ef al. (1976) bahwa penggunaan konsentrat yang lebih tinggi dalam ransum sapi potong dapat meningkatkan efesiensi pakan.

\section{Kesimpulan}

Kesimpulan yang dapat diambil dari penelitian ini adalah bahwa perbandingan hijauan dengan konsentrat dalam ransum berpengaruh nyata terhadap konsumsi BK, konsumsi PK, konsumsi TDN, tetapi berpengaruh tidak nyata terhadap pertambahan berat badan dan konversi pakan sapi jantan Peranakan Friesian Holstein (PFH).

Pengaruh yang timbul pada konsumsi (BK, PK dan TDN) lebih disebabkan oleh perbedaan berat badan dari materi-materi percobaan (sapi) yang digunakan, karena secara kualitatif ransum yang digunakan relatif sama (iso nitrogen dan iso energi). Hal ini terbukti dari hasil pertambahan berat badan yang dicapai adalah relatif sama.

\section{Ucapan Terima Kasih}

Penulis mengucapkan terima kasih kepada Ketua BMPTSI (sekarang APTISI) Wilayah VI Jawa Tengah atas bantuan biayanya serta segenap pimpinan dan karyawan perusahaan peternakan sapi perah "Mawar Mekar" Farm Gedong Karanganyar, Jawa Tengah yang telah memberikan ijin dan bantuannya sehingga penelitian ini dapat berlangsung.

\section{Daftar Pustaka}

Anonim 1998. Petunjuk Teknis Pemeliharaan Sapi Perah. Bag. Proyek Pengembangan Sapi Perah - BPT - HMT Baturraden.

Arora, S. P. 1989. Pencernaan Mikroba pada Ruminansia. Gadjah Mada Univ. Press. Yogyakarta.

Astuti, M. 1980. Rancangan Percobaan dan Analisa Statistik I. Bagian Pemuliaan Ternak. Fakulatas Peteternakan UGM. Yogyakarta.

Handayanta, E. 1994. Substitusi Konsentrat dengan Ampas Bir Fermentasi dalam Ransum terhadap Performan Sapi Jantan Friesian Holstein. Tesis S-2. Program Pascasarjana, UGM. Yogyakarta.

Jesse, G. W., G. B. Thomson, J. L. Clark, H. B. Hedrick and K. G. Weimer. 1976. Effects of ration energy and slaughter weight on composition of empty body and carcass gain of beef. J. Anim, Sci. 43 (2) : $418-425$.

Lomboan, A. 1992. Optimalisasi Pemberian Pakan untuk Peningkatan Produksi dan Kualitas Susu Sapi Friesian Holstein.
Miller,

NRC

Siregar

Sitorus

Sumadi 
Tesis S-2. Program Pascasarjana UGM. Yogyakarta.

Miller, W. J. 1979. Dairy Cattle Feeding and Nutrition. Academic Press. New York.

NRC. 1976. Nutrient Requirements of Beef Cattle. $5^{\text {th }}$ eds. National Academy of Sciences. Washington, DC.

Siregar, S. B 1994 Ransum Ternak Ruminansia. Penebar Swadaya Jakarta.

Sitorus, M., M. Zulbardi dan T. Manurung, 1991. Ransum berlevel energi tinggi bagi penggemukan sapi. Dalam Proc. Seminar Pengembangan Ternak Potong di Pedesaan. Fakultas Peternakan. Unsoed Purwokerto.

Sumadi, N Ngadiono dan Soeparno. 1991. Penampilan produksi sapi Friesian Holstein, Sumba Ongole dan Brahman
Cross yang dipelihara secara feedlot (penggemukan). Dalam Proc. Seminar Pengembangan Peternakan dalam Menunjang Pengembangan Ekonomi Nasional. Fapet Unsoed Purwokerto.

Suryapratama, W. 1989. Studi Imbangan Konsentrat Hijauan terhadap Penampilan dan Proporsi Asam Lemak Volatil Cairan Rumen pada Pedet Jantan Sapi Perah. Tesis S-2. Fak. Pascasarjana UGM. Yogyakarta.

Tillman, A. D., H. Hartadi, S. Reksohadiprodjo, S Prawirokusumo dan S. Lebdosoekojo. 1994. Ilmu Makanan Ternak Dasar. Cetakan ke 5. Gadjah Mada Univ. Press. Yogyakarta. 